\title{
Spinoza, Schopenhauer and the Standpoint of Affirmation
}

\author{
Bela EGyed
}

Spinoza's influence on German Idealism was remarkable. He was both a challenge and inspiration for the three major figures of this movement. ${ }^{1}$ Hegel, Schelling and Fichte all sought to define their own philosophical positions in relation to his. Schopenhauer, who despised these three philosophers to varying degrees of intensity (his vicious attacks on Hegel stand out), also had a similarly ambivalent relation to the sage of Amsterdam. How Spinoza came to influence Schopenhauer is not clear, but one might speculate. It could have come from his exposure to Fichte's lectures, from his conversations with Goethe or simply from being caught up in the postKantian attempt to rethink the Critical Philosophy. Still, his preoccupation with Spinozism is evident throughout his writings. Readers of his oeuvre cannot fail to note his ambivalence toward Spinoza's philosophy. He sees in Spinoza an ally against the feverish culture of the West. For example, in speaking about Spinoza and Giordano Bruno, Schopenhauer comments that:

They do not belong either to their age or to their part of the globe, which rewarded the one with death, and the other with persecution and ignominy. Their miserable existence and death in this Western world are like that of a tropical plant in Europe. The banks of the Ganges were their spiritual home; there they would have led a peaceful and honoured life among men of like mind (World I 422, n. 2).

Given Schopenhauer's respect for Hindu philosophy, comments like these indicate that he too felt intellectual kinship with Spinoza. Again, in the context of a rather favorable account of "the standpoint of affirmation" he notes that "[T]he philosophy of Bruno and that of Spinoza might 
also bring to this standpoint the person whose conviction was not shaken or weakened by their errors and imperfections" (World I 284). Elsewhere Schopenhauer points to more fundamental affinities as well. But he also criticizes Spinoza. And these criticisms, when they are not misguided, have to do with fundamental disagreements about the ultimate nature of reality and whether it is to be affirmed or denied.

In this paper I will argue that Schopenhauer's ambivalence toward Spinoza's philosophy is a reflection of an inner tension within his own doctrine of the denial of the will-to-live, and that his criticisms of Spinoza are related to his rejection of the standpoint of affirmation. ${ }^{2}$ In addition, I will also show that, if this tension is resolved in favor of the standpoint of affirmation, Schopenhauer's own ethics turns out to be closer to Spinoza's than he takes it to be. In making these arguments, I shall offer a suggestion about the possible relation of Schopenhauer's philosophy to two different strains of Buddhist philosophy: Theravada and Mahayana Buddhism.

Before discussing Schopenhauer's criticisms of Spinoza, let me outline the central features of his own philosophy. Schopenhauer is an ontological monist: for him the ultimate nature of reality is one. He is an epistemological dualist: this One reveals itself to knowing subjects as will and as representation. The most perfect phenomena (objectification/ representation) of the will are Ideas. These are eternal non-spatial entities whose only form is "being-object-for-subject." The forms of lower phenomena, of the world of everyday objects, are: space, time and causality. Phenomenal objects are what make up our world of everyday experience. Schopenhauer thinks that his conception of the two worlds brings together Kant's distinction between noumena and phenomena, the Vedantic conception of the Veil of Maya, and Plato's distinction between the real world and the world of appearance. When Schopenhauer says 
that representations are "objectifications" of the will at different degrees, he means that they are specific acts of the will.

Along with his ontology of immanence, Schopenhauer puts forth a two-tiered epistemology. Everyday objects can be known in accordance with the four principles of sufficient reason. Ideas, on the other hand, can only be grasped by a form of intuitive knowledge that Schopenhauer relates to aesthetic perception. The latter is an experience in which the knowing (pure) subject, having abandoned its narrow and selfish interests, becomes one with the (pure) object of knowledge. The inner nature of individuals, their "intelligible character," is also a pure act of the will, and as such, corresponds to a specific Idea. On several occasions Schopenhauer declares his affinities with Kant, Plato and Hindu philosophy (see, for example, World I 15). However, as I will suggest in a moment, his ontology of immanence brings him closer to Spinoza than to Kant, or to Plato, or to Vedantic philosophy. In fact, apart from some profound differences, due mainly to Schopenhauer's conception of the One as "will," and his emphasis on the aesthetic element in (pure) knowledge, one can see similarities between the way he relates Ideas to the will and to individual things, and the way Spinoza relates the attributes to "Substance" and its "modes." He even agrees with Spinoza (and Plato), in opposition to Kant, that there is a form of knowledge that can go beyond everyday human understanding.

It is beyond the scope of this paper to investigate in detail the difficulties involved in Schopenhauer's attempt to synthesize in a "single thought" Kantianism, Platonism, and Oriental Philosophy, or even to discuss the problems relating to his epistemology. Instead, I will first focus my attention on his views on morality, ethics, and salvation. Second, I will compare his criticisms of Spinoza on these subjects to what he himself says about them. In spite of a number of objections he has to Kant's moral philosophy, Schopenhauer does endorse the latter's 
conception of "intelligible" (noumenal) character. According to Kant, the reality of freedom is guaranteed only if human beings have, in addition to their empirical character, an a-temporal, non-spatial, intelligible character. In short, Kant believes that the only way to avoid the "absurdities" one is lead to by Spinozism is to embrace "transcendental idealism" (Kant 107): the view that our world of experience is constituted by the forms of our understanding. Schopenhauer leaves no doubt about his agreement with Kant on this point:

I regard Kant's doctrine of the coexistence of freedom and necessity as the greatest achievement of the human mind. With the Transcendental Aesthetic it forms the two great diamonds in Kant's crown of fame ... (Basis 111).

Kant's influence on the way Schopenhauer thinks about ethics is undeniable, but not without some significant modifications. He finds Kant's moral philosophy too formalistic and, for that reason irrelevant to the conduct of life:

... morality is concerned with the actual conduct of man, and not with a priori building of houses of cards to whose results no man would turn in the storm and stress of life (Basis 75).

Later on in the same essay (and in more detail in World I), Schopenhauer explains what he means by "ethics": "The purpose of ethics is to indicate, explain, and to trace to its ultimate ground the extremely varied behavior of man from a moral point of view" (130). Ethics, in other words, is the discovery of the three fundamental moral incentives motivating human behavior: egoism, malice and compassion (145). One way of understanding this distinction between morality and ethics would be to say that while morality has to do with human conduct, ethics goes deeper. It seeks to discover those human dispositions that motivate individuals to act in the ways that they do. This interpretation seems to be supported in the fourth book of World I (369), where Schopenhauer declares that conduct, deeds, are "merely empty figures, and only the disposition that leads to them gives them moral significance." He claims that a morality based on 
reason alone can motivate only by acting on self-love, and what springs from self-love can have no moral worth (World I 367). ${ }^{3}$ Genuine virtue, he says, cannot be "brought about through morality and abstract knowledge in general." It can be brought about "from the intuitive knowledge that recognizes in another's individuality the same inner nature as one's own" (World I 267-8). It is only by internalizing this knowledge that one can be morally just, and can refrain from willing beyond one's own body and from imposing one's will on another's. But even genuine virtue is not a sufficient condition for salvation. Salvation is obtained only when it is realized that beyond human justice there is "eternal justice," a justice which is a rule not of conduct but that of the world:

If we want to know what human beings, morally considered, are worth as a whole and in general, let us consider their fate as a whole and in general. This fate is want, wretchedness, misery, lamentation and death. Eternal justice prevails; if they were not as a whole contemptible, their fate as a whole would not be so melancholy. In this sense we can say that the world is the tribunal of the world (World I 352).

These are, indeed, harsh words, but for someone like Schopenhauer who endorses them, it can only have one meaning: all life and all existence itself is contemptible, and there can only be one admissible response to it: to deny it.

In a particularly forceful passage of World I, Schopenhauer declares that those who see through the principle of individuation will not be consoled by momentary respite from suffering. Having recognized the true nature of things-in-themselves, "there arises in him a strong aversion to the inner nature whose expression is his own phenomenon, the will-to-live, the kernel and essence of that world recognized as full misery. He therefore renounces precisely this inner nature ..." (380). However, it is not clear what Schopenhauer means by denial of the "will-tolive," or, indeed, what he means by the "denial of the self." He himself has great difficulty in articulating a "positive" statement of the doctrine. In the last section of the same work (sec. 71), 
Schopenhauer is still struggling to give an adequate philosophical account of his doctrine of denial. On the one hand, he admits that having recognized that the inner nature of the world is will, and having seen in all its phenomena only the objectivity of the will, we cannot evade the consequence that "with the free denial, the surrender, of the will, all those phenomena are also abolished ... No will: no representation, no world" (World I 410-11). On the other hand, perhaps in order to mitigate the awkward implications of this positive, philosophical, version of his doctrine, he invites his readers to turn their glance to "those who have overcome the world, in whom the will, having reached complete self-knowledge, has found itself in everything, and then freely denied itself ... [so that we may] see that peace that is higher than all reason, that oceanlike calmness of the spirit, that deep tranquility, that unshakable confidence and serenity" (World I 411). Apart from the reference to self-denial, this last passage could also describe those who affirm the will with "better knowledge": a disinterested knowledge through Ideas. And even selfdenial, construed as denial of the self which is mired in "vehement willing," could be consistent with affirmation. However, before turning to a confrontation between Schopenhauer's and Spinoza's "metaphysical ethics," I need to say a few more words about Schopenhauer's views on the standpoint of the affirmation of the will-to-live.

I will pass over one aspect of Schopenhauer's critique of the affirmation of the will-tolive, because if that is all he means by affirmation, his critique of it would have no philosophical interest. At times, in criticizing the affirmation of the will-to-live, Schopenhauer places the emphasis on the "sexual impulse." It will be recalled that, according to Schopenhauer, wrongdoing (wickedness) is willing beyond one's own body. ${ }^{5}$ The "sexual impulse," with its double aspect—vehement willing (affirmation of life) beyond one's body in the sexual act, and willing (affirming) beyond one's body, consciously or unconsciously, in procreation-seems to 
fit Schopenhauer's definition of wickedness. However, if this were all that Schopenhauer could offer as argument against the standpoint of affirmation, he would gain only a pyrrhic victory. Neither vehement sex, nor feverish reproduction is an essential feature of a thoughtful standpoint of affirmation. (Neither Spinoza nor the Stoics could be accused of advocating either.)

Schopenhauer's most interesting discussion of the standpoint of affirmation comes at the beginning of book four of World I. His account of affirmation there is intimately connected to his views on intelligible character. So, once again we need to go back to Kant. As I noted earlier, Schopenhauer found Kant's distinction between noumenal ("transcendental") freedom and phenomenal necessity one of the great achievements of the human mind. But in Schopenhauer's philosophy, Kant's cautious remarks about transcendental freedom are transformed into a robust ontology of personhood. In Schopenhauer's hands, “intelligible character" becomes the immutable "inner being of man-in-himself" (Basis 97). It is the fundamental disposition by virtue of which individuals come to possess the moral qualities they do have. By "empirical character," Schopenhauer means the "temporal unfolding of an extra temporal, and so invisible and unalterable, act of will, or of intelligible character" (World I 301). In other words, one may get an inferential knowledge of one's empirical character by reflecting on the sum total of one's conduct. A bad person, for example, may change his/her conduct, acquiring a character more suitable to living, thereby avoiding situations which would "trigger" his/her (bad) intelligible character, causing ${ }^{6}$ him/her to act in a harmful way. But one cannot change one's intelligible character. It is in this sense that our "freedom" to act does not involve a morally relevant free choice. Our choices are strictly determined by who we are, essentially:

I do what I will: I can, if I will, give everything I have to the poor and thus become poor myself-if I will. But I cannot will this, because the opposing motives have much too much power over me to be able to do so. On the other hand, if I had a different character, 
even to the extent that I were a saint, then I would be able to will it. But then I could not keep from willing it, and hence I would have to do so (Schopenhauer, Freedom 45).

What we are, essentially, is an act of the will, and, for this reason, according to Schopenhauer, we are not morally responsible for what we do, but only for what we are. Still, even assuming that moral responsibility pertains to who one is, and not to what one does, one may ask how anyone can be responsible for what one is if one cannot choose one's essential (intelligible) character. Schopenhauer flirts with the idea of metempsychosis (World I 356, 365), but a more ambitious attempt to solve this problem "philosophically" is based on his ontology of the will:

In the light of our whole view, the will is not only free, but even almighty, from it comes not only its actions, but also its world: and as the world is, so does its action appear, so does its world appear ... The will determines itself, and therewith its action and its world also; for besides it there is nothing (World I 272).

But, so far, all this proves is that the will is omnipotent, autonomous, and, therefore, absolutely free. It does not prove that persons-intelligible characters-are also free. ${ }^{7}$ By way of proof, Schopenhauer offers a strange, and, in my view, deeply flawed argument in favor of human freedom and moral responsibility. He argues that since the will-like the Kantian thing-initself - is not subject to the categories of the understanding, and does not admit of division, it is completely present in all its phenomena.

If, according to what has so far been said, all variety of forms of nature and all plurality of individuals belong not to the will, but only to its objectivity and to the form thereof, it necessarily follows that the will is indivisible and wholly present in every phenomena although the degrees of its objectification, the (Platonic) Ideas, are very different (World I $155)$.

Intelligible characters are free acts of the will at different degrees of objectification, and "can be regarded as a special Idea" (World I 158). In its act, the will is absolutely free and wholly present. But these acts are different, giving rise to different characters. This poses a problem: if the will is wholly present in all its acts, then all (individual) characters are equally free; however, 
if each character is a different degree of objectification of the will, then there is an essential difference between them. The question, then, is "What is this difference?" Is it a difference in freedom, and if it is not, how can it be a morally significant difference? But Schopenhauer is committed to saying that there are morally significant differences between individuals. Some are wicked, others are selfish, and a very few are compassionate. Presumably, the degree to which the will is objectified in each individual character is what determines their moral quality-the lowest degree corresponding to the best, and the highest to the worst—but not their responsibility. Since they are acts of the same will, they are all equally free and responsible for whom they are. So, it seems that, in the end, responsibility and morality are independent of one another.

However, Schopenhauer has two arguments aiming to avoid, or at least mitigate, the problem posed above. On the (merely) moral level, on the level of conduct, he argues that individuals are responsible because they feel the "sting of conscience." It is the sting of conscience that shows us who we are, and that we are responsible for what we are. ${ }^{8}$ But this argument gets us nowhere. My sting of conscience might give me an "intuitive perception" into my essential character, but it does not show me how, and why, I am responsible for that character. Schopenhauer offers a more satisfactory, though somewhat paradoxical, argument with his discussion of "eternal justice." This justice is beyond morality and conduct. It pertains entirely to who we are. And, as we have seen in the previously quoted passage from World I (352), we are all equally responsible, worthless, and contemptible. So, the only ethically "worthy" option left to us is to deny the will-to-live. With this we are finally brought to the central issue of this paper: what is it to deny, or to affirm, the will-to-live? 
Schopenhauer's notions of "Idea" and "intelligible character" are central to his discussion of the affirmation or denial of the will-to-live. And, since the intelligible character of an individual is, in itself, an act of will (of a pure willing subject), and in so far as this character can be an object of "pure" knowledge (an Idea), the question of the affirmation or denial of the willto-live, or the question of the denial or affirmation of the self, is intimately related to the question of how pure knowledge is related to pure willing. I take this last question to be at the centre of Schopenhauer's philosophy. Also, I believe that the way in which one answers this question determines one's decision in favoring one or the other of the two standpoints Schopenhauer discusses in the last book of World I.

One of the main tasks of the third book of World I is to describe the kind of knowledge that goes beyond "merely" rational knowledge. Unlike the type of knowledge that Schopenhauer associates with selfish willing in accordance with the Principle of Sufficient Reason, this is a "better knowledge"": a knowledge of the Idea which,

Takes place suddenly, since knowledge tears itself free from the service of the will precisely by the subject's ceasing to be merely individual, and being now a pure will-less subject of knowledge (World I 178).

The key question here is whether the pure will-less subject is still a "subject." There are a number of reasons Schopenhauer is committed to accepting that this is so. First, if my individual character corresponds to a specific Idea, in the pure knowledge of this specific Idea I know something specific: an individual. Second, a will-less subject, having torn itself from the service of the narrow, selfish, will, is still a subject that now wills, not as an (illusory) empirical subject burdened with wants, but as a pure act of the will. Finally, even in the denial of the will, as Schopenhauer understands it, some kind of pure subjectivity is at work. In fact, there are 
passages in The World as Will and Representation where Schopenhauer seems to say as much.

This is the description he gives of the standpoint of affirmation:

The will affirms itself; this means that while in its objectivity, that is to say, in the world and in life, its own inner nature is completely and distinctly given to it as representation [I would add here as "Idea"], this knowledge does not in anyway impede its willing. It means that just this life thus known [I would add "with better knowledge"] is now willed as such by the will with ["better"] knowledge, consciously and deliberately, just as hitherto the will willed it without knowledge and as a blind impulse (World I 285).

Schopenhauer never spells out clearly how one comes to have a (pure) knowledge of the Idea of one's intelligible character. His discussion of aesthetic experience, interesting as it is, does not seem to be sufficient. In order to know that one is one with the world Will, one has to know more about the world than is available in an aesthetic experience. But he does say that this knowledge is presupposed by the "philosophical"10 route to denial. He suggests that while better knowledge is required for the denial of the will-to-live, all willing ends with that knowledge. Evidently, his case against the affirmation of the will-to-live rests on construing all willing as willing with motives - as "vehement" willing (World I 285). But, if we pay close attention to what he says about the pure knowledge of who we are, we see that another kind of willing, as well as another kind of knowing, can be attained by it. And, at the very end of World I, Schopenhauer hints toward that possibility—when he speaks of denial, not as "the complete abolition of knowledge ... with which the rest of the world would of itself also vanish into nothing" (380), but as "that ocean-like calmness of the spirit, that deep tranquility, that unshakable confidence and serenity" (411). But this state of the spirit can also be present in a higher form of affirmation. ${ }^{11}$ In short, notwithstanding Schopenhauer's insistence to the contrary, there is, even on his own terms, no more philosophical justification for the kind of denial associated with asceticism than there is for affirmation associated with better knowledge. That 
life is unpredictable, and that suffering might befall us in spite of our best efforts to avoid it, is no ground for denying it. And, even if asceticism were practiced honestly and rigorously, it would add nothing to the spiritual enlightenment provided by "better knowledge," the knowledge that beyond one's narrow self there is a life in which one can participate without the burden of need, greed, and hostility.

We have finally arrived at the confrontation between Schopenhauer's and Spinoza's philosophies. Schopenhauer has basically two objections to Spinoza's ethics. The first is that in so far as Spinoza is a pantheist, his ethics is bound to be optimistic:

Now, it is true that I have that "one and all" in common with the Pantheists but not their "all is god" ... they are thus put in the position of having to sophisticate away the colossal evils of the world (World II 643).

The second objection is that since Spinoza's ethics has only a tenuous connection with his ontology, he is committed to seeing the difference between good and evil as merely conventional (World II 590). Such an ethics is, in Schopenhauer's words, not only "hollow and empty," but “astounding," "abominable," "absurd," and even "revolting" (World II 645). His attacks on Spinoza are directed primarily against Chapter XVI of Tractatus Theologico-Philosophicus, and Ethics IV, Prop. 37. The following passage is an accurate reflection of how he sees the difference between Spinoza's and his own ethics:

Only the metaphysics is actually and immediately the support to ethics which is itself originally ethical and is constructed from the substance of ethics, namely the will. Therefore, I could have called my metaphysics "ethics" with much more better reason than Spinoza. With him this looks almost like an irony, for only by sophism could he tack morality ${ }^{12}$ onto a system from which it would never consistently issue. Also, with almost revolting assurance he mostly denies it flatly (Nature 140).

Let me begin by commenting on Schopenhauer's first objection. If it is possible to call Spinoza a "pantheist," he can by no means be called an "optimist." He is no more an optimist than he is a 
pessimist. There is no suggestion by Spinoza that the "inner nature" of the world is good, or that it is evil, or even that it is the source of joy or suffering. Spinoza's God acts out of the necessity of its nature. It is not blind, but neither does it act in conformity with human values and expectations. Human beings could come to know God through the "third type" of knowledge, ${ }^{13}$ which is, like Schopenhauer's "better knowledge," a form of intuition. The most significant difference between these two versions of intuitive knowledge is that the first can only be attained after the work of rational knowledge has been completed, whereas the second is attainable through a form of aesthetic perception. What Schopenhauer takes to be Spinoza's "optimism" is the belief that through an understanding of the way in which God's attributes are expressed in finite individuals (modes), human individuals can come to know and, as a result, acquiesce in the order of things, of which they, too, are an essential expression.

Both Spinoza and Schopenhauer have to come to terms with the problem of individuation posed by their respective ontologies of immanence. As we have seen, Schopenhauer does this by means of his notion of "objectification." Spinoza does it by means of his notion of "expression." And, corresponding to Schopenhauer's "intelligible character," we find in Spinoza the modal essence of human individuals. In book five of the Ethics, Spinoza entertains the idea of "eternity." This must mean that human beings may come to see themselves as eternal insofar as they come to know that their existence is an expression of the complex of causes that constitutes the order of nature. Naturally, Schopenhauer's commitment to transcendental idealism precludes causal knowledge of the nature of reality independently of perceiving subjects. However, on that account he is, like Kant, faced with the problem of a radical epistemological dualism, but, unlike Kant, he is obliged, by his monistic ontology, to establish some kind of internal connection between the realm of the will and that of representation. He does this by claiming that the world 
of representation is an objectification of the will in which it "mirrors" itself. However, he is unable to give an adequate account of the mechanism of this objectification. His theory of Ideas-in my view the weakest aspect of his philosophy since it precludes any reference to rigorous conceptual and empirical analysis-comes across as artificial and, from a modern scientific point of view, amateurish. ${ }^{14}$ "Better knowledge" of who we are, what our essential character is, cannot come simply from "perceptual intuition." If we are to know our essential nature, we need to know the essential nature of our world and our relation to it. ${ }^{15}$

At this point Schopenhauer might reply that it is optimistic to claim that it is possible to know the complex of causes constituting us with any degree of certainty since such a claim ignores the fact that human existence and, indeed, the world itself, are fraught with unpredictability. It is true that for Spinoza contingency pertains not to nature but only to our limited knowledge of it. As our knowledge grows, the less contingent the world appears to us. We attain salvation, according to Spinoza, by affirming necessity, and by giving up all hope that the world, and our essential selves, will conform to our mundane desires and imaginings. In this, his view resembles Schopenhauer's. Both of them think that we cannot change our essential character, and both of them think that through knowledge we can bring our existence into greater harmony with it.

The last point brings me to Schopenhauer's second objection to Spinoza's ethics: that it has only a tenuous connection with his ontology and, for that reason, it is merely conventional, and even "revolting." ${ }^{.16}$ Previously, I mentioned that according to Schopenhauer, the morality of reason is motivated by love of self alone. Presumably, this is how he sees Spinoza's ethics. And, on a superficial reading of Spinoza, his criticism may appear to be justified. Spinoza is a rational egoist. In his view, the natural right of an individual is not limited by "sound reason."17 It is 
limited only by the desire and power of the individual. But does this position differ from Schopenhauer's? In Schopenhauer's view, too, every individual does what he/she wills, and, most are selfish. Even those who are not are so because of what they are. Also, in his view those who achieve "better knowledge" can affirm life and themselves, having been freed from narrow self-interest.

A striking feature of Schopenhauer's comments on Spinoza is the absence of any reference to the latter's doctrine of conatus, the striving on the part of finite existing modes to maintain themselves in existence. ${ }^{18}$ Given that in all his arguments against the affirmation of the will-to-live striving and struggle play a central role, this silence is perplexing. For, it is clear that in Spinoza's view God's power to act does not involve any striving. It would make no sense to think that a being that exists necessarily would strive to maintain itself in existence. By contrast, finite existing individuals do strive to maintain themselves in existence. During the course of their lives, existing individuals may encounter obstacles, some of which might even destroy them. Reasonable individuals would want to arrange these encounters in such a way that they enhance their power to exist. From the point of view of these reasonable individuals, life is, indeed, full of danger and uncertainty. By way of contrast, those who are ignorant will strive blindly under the influence of external causes. ${ }^{19}$

At this point an important difference between Spinoza's and Schopenhauer's conception of "self-interest" emerges. Even though Schopenhauer recognizes that there is a difference between intelligible and empirical character, and even though he admits that through a "better knowledge" one may come to know one's intellectual character-in other words, one's essential self-he fails to distinguish between a striving that affirms one's essential self and one that is blind, selfish, and ignorant of what one really is. As I have suggested earlier, this is a 
consequence of his particular way of appropriating Kant's transcendental idealism, and the dualism associated with it. In short, his appropriation of the Kantian notion of "noumenal freedom" commits him to the position that the empirical individual is not free, but that the intelligible character, in so far as it is a pure act of the will, is. But what is lost in this way of approaching the question of freedom is the notion that, under certain circumstances-if the individual is wise- the individual can be free. By contrast, Spinoza, who also denies that individuals have a free choice, allows for individual freedom: the freedom that comes from grasping that one is a specific expression of the infinite power of God (natura naturans). This allows Spinoza to claim that salvation comes, not through the denial of the will-to-live ("conatus," in his terminology) but through its affirmation. Spinozistic affirmation, I suggest, is the affirmation of self, not against, but along with the affirmation of nature. This, I think, is what he means by his notion of the "intellectual love of God." This love is, first of all, the recognition that one is merely a finite mode of an infinite complex of causes ${ }^{20}$ (our love of God); secondly, it is the recognition that within this complex of causes our power to act has its essential role (God's love toward us).

Earlier, I suggested that Schopenhauer could have adopted a more favorable attitude towards the standpoint of affirmation, and that at times he comes close to doing just that. ${ }^{21} \mathrm{He}$ opts for denial for a number of reasons, none of which are very strong. He sees that there is a lot of suffering in the world. He recognizes that existence is full of uncertainties and that, consequently, the hope of lasting happiness is in vain. He is right on both counts, but that alone does not support the radical form of denial of the will-to-live that he advocates. His attacks on the standpoint of affirmation trade on construing affirmation as striving blindly in the pursuit of narrow self-interest, against all comers. He claims that those who have attained better knowledge 
of themselves and of the world have but only one choice: to deny both. This might be right only if what they are supposed to deny is the world of illusion, which is Spinoza's "first type" of knowledge ("imagination"). But then, he would have to agree with Spinoza. Better knowledge, understood this way, does not stop with the recognition that a life of want, greed and aggression leads to suffering. It offers the prospect of a more serene existence; one that acquiesces in the infinite power of the Universe, and rejoices in the small role that a finite individual can play in it.

We can say of Schopenhauer's second criticism of Spinoza's ethics that it is weak for two reasons. It is weak because it fails to see that, as far as ordinary morality goes, there is no significant difference between them. They both acknowledge the importance of selfenhancement for ordinary moral consciousness. And, they both acknowledge the important role consensus plays in the deliberation of reasonable people. It is also weak because it has an inadequate, narrowly instrumentalist, notion of the nature of reason and its role in ethics. What Schopenhauer calls properly ethical follows from his view that the ultimate nature of reality is will. His extreme pessimism about existence-combined with his conception of the double relation the will has with its pure acts (intelligible characters), and with the world of representation-leads him to say that the only truly ethical stance is the denial of the will-to-live.

This brings us to the last question: could Schopenhauer's metaphysics of the will be more appropriately called an "ethics" than Spinoza's metaphysics of infinite Substance? Schopenhauer holds the view that the properly ethical stance, compassion, comes from the same source as the denial of the will-to-live (World I 378). He claims that once we recognize that as pure acts of the same will we are all identical, we experience all suffering as our own. However, apart from the problem of individual identity mentioned above, ${ }^{22}$ there is the question of what follows from his "metaphysical ethics" for the conduct of our life. In the context of discussing "acquired 
character" (World I, sec. 55), Schopenhauer does have something to say about the conduct of life, but he dismisses the problem of how one becomes who one is, as irrelevant to what is properly "ethical." Once again, if by having "acquired character" we mean having "better knowledge," namely, that "knowledge tears itself free from service to the service of the will precisely by the subject ceasing to be merely individual, and being a pure will-less subject of knowledge" (World I 178), then we reach what Spinoza calls "blessedness,"23 the high point of his ethics. The only reason Schopenhauer might have for denying that Spinoza has a proper ethics is that he can only see freedom as "noumenal freedom" in the Kantian sense, and not as power to act (and to be), as Spinoza understood it. So, we see that Schopenhauer's criticism of Spinoza's ethics relies on the problematic Kantian conception ${ }^{24}$ of noumenal freedom, modified by an equally problematic conception of noumenon as "will."

It might be suggested, as I have tried to argue in this paper, that Schopenhauer's ambivalence towards Spinoza is a reflection of a deeper tension: his inability to articulate clearly the difference between the standpoint of affirmation and the standpoint of denial. This, in turn, might be related to other tensions, ones relating to the way he appropriates Kant, and the way he appropriates Eastern philosophy. Maybe Schopenhauer is not as original a thinker as he believed himself to be, but his effort to articulate such diverse philosophical perspectives as Kantianism, Hinduism, and Platonism makes him an interesting one. 


\section{Notes}

${ }^{1}$ A very detailed examination of Spinoza's influence on German Idealism is given in Jean-Marie Vaysse's Totalite et Subjectivite: Spinoza dans l'Idealisme Allemand.

${ }^{2}$ For Schopenhauer true salvation is possible only through the denial of the will-to-live.

3 By saying this he manages both to accept Kant's view (self-love cannot be the basis of morality) and to reject it (morality, if it is to have any relevance to conduct, if it is to motivate, must be based on self-love).

${ }^{4}$ Most of the chapter in World II, "On the Affirmation of the Will-to-Live," is devoted to the "sexual impulse." Schopenhauer also connects affirmation and the sexual instinct in World I (see, for example, 328-9).

5 A clear statement of how moral wrong and vehement willing is connected can be found at World I 362-3.

${ }^{6}$ In an attempt to avoid the embarrassing consequence of having to admit a causal relation between noumena (intelligible character) and phenomena (acquired character), and at the same time making room for moral deliberation, Schopenhauer invokes Malebranche's theory of "occasional causation." In other words, an individual's intelligible character is the "occasional" cause of that person's conduct in a given situation. For a discussion of this matter, see World I $137-9$.

${ }^{7}$ Note the way Schopenhauer slides over this problem: "My philosophy, however, is the only one that grants to morality its complete and entire rights; for only if the true nature of man is his own will, consequently only if he is, in the strictest sense, his own work, are his deeds actually entirely his and attributable to him." I take this to be one of the major weaknesses of Schopenhauer's philosophy: he seems to be oblivious to the problem of "individuation" that is posed by remarks like these.

${ }^{8}$ At Basis 112-3, Schopenhauer actually makes this argument.

${ }^{9}$ Schopenhauer uses this term favorably throughout the latter half of World I (see, for example, $253,353,368$ and 403).

${ }^{10}$ He suggests that there is another route, through intense suffering, which does not require knowledge of who we really are.

11 The kind of ambivalence I noted in Schopenhauer is also reflected in the reactions of his commentators. For example, David Cartwright, in "Seeing Through the Principle," suggests that by his asceticism Schopenhauer is "grossly unfair to the phenomenal world" and that his "is a form of anthropocentrism choking itself." By contrast, R.G. Morrison, in Nietzsche and 
Buddhism, leans toward a favorable, non-nihilistic, interpretation of the denial of the will-to-live. Still, he does not go as far as I would want to go, and even blurs the line between some sense of denial and some sense of affirmation. The same "blurring" is made by some Buddhist scholars between Nirvana and Samsara, suggesting that Nirvana is possible within Samsara (the phenomenal world).

12 Note the shift from "ethics" to "morality" in this passage. Is it alleged that Spinoza denies ethics, or is it alleged that he denies morality? This is a key distinction that Schopenhauer does not make.

13 Spinoza distinguishes three types of knowledge: 1. imagination, based on confused and mutilated ideas which are ignorant of the true causes of things; 2. reason, which has clear and distinct ideas of the causal relation between things; and 3. intuition, which sees the totality of all causes as they are expressed in singular things: "The third kind of knowledge depends on the mind, as on a formal cause, in so far as the mind is eternal" (Ethics V, Prop. 31).

14 It hardly needs to be argued that, even from the perspective of $19^{\text {th }}$ century philosophy of science, Schopenhauer's comments on the subject are very deficient.

15 In Spinoza's words: "He who understands himself and his affects clearly and distinctly loves God, and does so more, the more he understands himself and his affects" (Ethics V, Prop.15).

${ }^{16}$ Schopenhauer might, with some justification, think that Spinoza's views on the treatment of animals are revolting. However, what he must have in mind in the above quotation is Spinoza's claim, in chapter XVI of Tractatus that: "The natural right of the individual man is thus determined, not by sound reason, but by desire and power" (201).

17 "The natural right of the individual man is thus determined, not by sound reason, but by desire and power" (201).

18 "The striving of a thing [its conatus] by which a thing strives to preserve in existence is nothing but the actual essence of the thing" (Ethics III, Prop.7).

19 "For the ignorant man is not only distracted in various ways by external causes without ever gaining the true acquiescence of his spirit, but moreover lives, as it were unwitting of himself, and of God, and of things, and as soon as he ceases to suffer, he ceases to be. Whereas the wise man, in so far as he is regarded as such, is scarcely at all disturbed in spirit, but, being conscious of himself, and of God, and of things, by a certain eternal necessity, never ceases to be, but always possesses true acquiescence of his spirit" (Ethics V, Prop. 52, Schol.).

${ }^{20}$ This infinite complex of causes is God who is, at the same time, "cause of itself."

${ }^{21}$ Moira Nicholls, in "Influences," shows that Schopenhauer's relation to Eastern philosophy had undergone changes through different editions of World I. This might also account for his 
ambivalence about affirmation and denial of the will-to-live. The radical asceticism that he espouses in most of the fourth book of World $I$ is more in line with Theravada Buddhism than with Mahayana Buddhism, whereas his position at the very end of the work (409-10) is leaning toward Mahayana Buddhism. By contrast, Spinoza's notion of "blessedness" is closer to this latter form of Buddhism, and is also more consistent with the ontology of immanence to which they both aspire.

${ }^{22}$ See note 7 above. On the one hand, Schopenhauer wants to say that "the true nature of man is his own will," in order to safeguard morality; on the other hand, he wants to say, in making a case for "compassion," that as acts of the same will, there is no difference in the nature of one person or another. Because Spinoza maintains that singular modes do not lose their identity, he does not have this problem.

${ }^{23}$ It is significant that immediately after the above remark Schopenhauer notes that, "It was this in Spinoza's mind when he wrote 'the mind is eternal in so far as it conceives things from the standpoint of eternity' [Ethics, V, Prop. 31, Schol.]” (World I 179).

${ }^{24}$ Without going into detail, it may be said that the Kantian conception is problematic because it either denies real freedom (we must act "as if" we were free), or if it allows real freedom it is purely transcendent.

\section{Works Cited}

Cartwright, David. "Seeing Through the Principle of Individuation." Schopenhauers Actualitat. Ed. Wolfgang Schirmacher. Vienna: Passagen Verlag, 1988. 41-48.

Kant, Immanuel. Critique of Practical Reason. Trans. Lewis White Beck. New York: Macmillan, 1993.

Morrison, Robert G. Nietzsche and Buddhism. Oxford: Oxford University Press, 1997.

Nicholls, Moira. "The Influences of Eastern Thought on Schopenhauer's Doctrine of the Thingin-Itself." The Cambridge Companion to Schopenhauer. Ed. Christopher Janaway. Cambridge: Cambridge University Press, 1999.

Schopenhauer, Arthur. The World as Will and Representation. 2 Vols. Trans. E.F.G. Payne. New York: Dover Books, 1958 [Volumes I and II originally published in 1819 and 1844, respectively]. 
-. Essay on the Freedom of the Will. Trans. Konstantin Kolenda. Indianapolis: Bobbs Merrill, 1960 [Originally published in 1839].

-. On the Basis of Morality. Trans. E. F. G. Payne. Indianapolis: Bobbs-Merrill, 1965 [Originally published in 1841].

—. On the Will in Nature. Trans. Mme. K. Hillebrand. London: G. Bell, 1903.

Spinoza, Benedict. The Ethics. Trans. Edwin Curley. Princeton: Princeton University Press, 1994.

—. A Theologico-Political Treatise. Trans. R. H. M. Elwes. New York: Dover, 1951.

Vaysse, Jean-Marie. Totalite et subjectivite: Spinoza dans L'Idealisme Allemand. Paris: Vrin, 1994. 